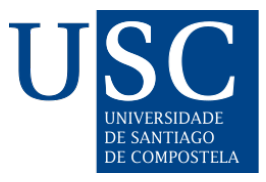

REVISTA INTERNACIONAL de

COMUNICACIÓN y DESARROLLO

Revista Internacional de Comunicación y Desarrollo (RICD), 4(15), 2021. ISSN-e: 2386-3730

https://doi.org/10.15304/ricd.4.15.8182

\title{
CONVOCATORIA DE COLABORACIONES
}

\section{Revista Internacional de Comunicación y Desarrollo, n¹6, julio 2022}

Fecha límite: 15 de abril de 2022.

La convocatoria para el envío de artículos científicos para el número 16 se encuentra abierta. El plazo de recepción de los artículos está abierto hasta el 15 de abril de 2022 . Una vez revisados, se comunicará su aceptación. En este número 16, que se publicará online en julio de 2022, se priorizarán, aunque no de manera excluyente, aquellos artículos de investigación que aborden aspectos relacionados con:

\section{Encuentros y desencuentros entre la Economía Política de la Comunicación y los Estudios Culturales.}

2. Pobreza, hambre y migración en las agendas formativas e informativas.

La Revista Internacional de Comunicación y Desarrollo de REAL-CODE (Red Europa y América Latina de Comunicación y Desarrollo https://www.real-code.org/), editada por el Servicio de Publicaciones e Intercambio Científico de la Universidade de Santiago, es una revista online de difusión científica que ofrece una lectura crítica sobre Comunicación y Desarrollo. Pretende dar prioridad a las investigaciones que se realicen en ambos campos y sus interrelaciones, alentando los estudios que cuenten con la participación y el apoyo de las bases sociales.

RICD es una publicación abierta a todas aquellas personas que aporten nuevos puntos de vista y metodologías que aborden la realidad social. RICD está indexada a Latindex, ERIH Plus, MIAR, Dulcinea y Dialnet.

RICD asume una estricta política de revisión en su sección de artículos de investigación, por doble ciego (double blind; peer reviewed).

RICD sólo publica artículos de investigación inéditos. Los revisores de los artículos podrán señalar al equipo de edición de la revista aquellos textos que incumplan las más básicas normas éticas respecto de la re-edición o el plagio, y se retirarán de la edición en curso aquellos que por este motivo sean rechazados. RICD se reserva el derecho de admitir en el futuro nuevos textos de aquellos autores que incumplan estas normas.

RICD no se hará cargo de la revisión de las citas en texto, referencias bibliográficas según las normas APA ni de la inclusión de los DOI, en caso de su existencia. De este modo, no se aceptará ningún artículo en el que no estén cuidadosamente revisados y cumplidos estos criterios por parte del autor. 
Los resúmenes y originales deben de formalizarse en lengua española, portuguesa, gallega y/o inglesa, siguiendo las directrices de la revista:

http://www.usc.es/revistas/index.php/ricd/about/submissions\#authorGuidelines.

Los autores incluirán siempre en sus textos originales traducción de los títulos, resúmenes, palabras clave, sumarios y nota biográfica al inglés, inmediatamente después de disponerlos en el idioma del texto original, si este no es ya en lengua inglesa.

\section{CALL FOR PAPERS}

\section{Revista Internacional de Comunicación y Desarrollo, Num. 16, April 2022}

\section{Deadline: April, 15, 2022.}

The call for the submission of research articles for Issue 15 is open. The deadline for the submission of articles is April, 15, 2022. Once articles have been reviewed by RICD, authors will be notified of paper acceptance. Issue 16, that will be published online in July 2022 , will preferently contain research articles related to the following lines of work:

\section{Encounters and misunderstandings between the Political Economy of Communication and Cultural Studies.}

\section{Poverty, hunger, and migration in the formative and informative agendas.}

The International Journal of Communication and Development from REAL-CODE (Red Europa y América Latina de Comunicación y Desarrollo https://www.real-code.org/), edited by the Service of Publications and Scientific Exchange of the University of Santiago de Compostela, is an online biannual journal of scientific dissemination which offers a critical interpretation about Communication and Development. We prioritize researches relating to both fields and their interrelations, especially those studies that count on the participation and support by social agents.

RICD is an open publication for those who want to share new methodologies and points of view related to social reality. RICD is indexed in Latindex, ERIH Plus, MIAR, Dulcinea and Dialnet.

RICD has a strict policy of revision in the section of research articles. We assume the doubleblind procedure and also the peer review.

RICD only accepts research articles never published previously. Reviewers will notify the editorial board if an article breaks basic ethical rules as re-edition or plagiarism. Those texts will be excluded from the edition in progress. RICD reserves the right to accept in the future new texts by those authors who have broken these guidelines.

RICD will take no responsibility for the review of the quoting, bibliographic references according to the APA style nor DOI inclusion, in case it proceeds. Thus, articles that do not meet these requirements will not be accepted.

The summaries and the originals must be formalized in Spanish, Portuguese, Galician language and/or English, according to the publication guidelines:

http://www.usc.es/revistas/index.php/ricd/about/submissions\#authorGuidelines.

After the original text, authors must always include the English translation of titles, summaries, key words, contents and biographical notes. 


\section{CONVOCATORIA DE COLABORACIONES}

\section{Revista Internacional de Comunicación y Desarrollo, $n^{\circ} 17$, diciembre 2022 - enero 2023}

\section{Fecha límite: 15 de octubre de 2022.}

La convocatoria para el envío de artículos científicos para el número 17 se encuentra abierta. El plazo de recepción de los artículos está abierto hasta el 15 de octubre de 2022. Una vez revisados, se comunicará su aceptación. En este número 17, que se publicará online entre los meses de diciembre de 2022 y enero de 2023, se priorizarán, aunque no de manera excluyente, aquellos artículos de investigación que aborden aspectos relacionados con:

\section{Los ODS 14 y 15 en las agendas formativas e informativas. 2. Desinformación.}

La Revista Internacional de Comunicación y Desarrollo de REAL-CODE (Red Europa y América Latina de Comunicación y Desarrollo https://www.real-code.org/), editada por el Servicio de Publicaciones e Intercambio Científico de la Universidade de Santiago, es una revista online de difusión científica que ofrece una lectura crítica sobre Comunicación y Desarrollo. Pretende dar prioridad a las investigaciones que se realicen en ambos campos y sus interrelaciones, alentando los estudios que cuenten con la participación y el apoyo de las bases sociales.

RICD es una publicación abierta a todas aquellas personas que aporten nuevos puntos de vista y metodologías que aborden la realidad social. RICD está indexada a Latindex, ERIH Plus, MIAR, Dulcinea y Dialnet.

RICD asume una estricta política de revisión en su sección de artículos de investigación, por doble ciego (double blind; peer reviewed).

RICD sólo publica artículos de investigación inéditos. Los revisores de los artículos podrán señalar al equipo de edición de la revista aquellos textos que incumplan las más básicas normas éticas respecto de la re-edición o el plagio, y se retirarán de la edición en curso aquellos que por este motivo sean rechazados. RICD se reserva el derecho de admitir en el futuro nuevos textos de aquellos autores que incumplan estas normas.

RICD no se hará cargo de la revisión de las citas en texto, referencias bibliográficas según las normas APA ni de la inclusión de los DOI, en caso de su existencia. De este modo, no se aceptará ningún artículo en el que no estén cuidadosamente revisados y cumplidos estos criterios por parte del autor.

Los resúmenes y originales deben de formalizarse en lengua española, portuguesa, gallega y/o inglesa, siguiendo las directrices de la revista:

http://www.usc.es/revistas/index.php/ricd/about/submissions\#authorGuidelines.

Los autores incluirán siempre en sus textos originales traducción de los títulos, resúmenes, palabras clave, sumarios y nota biográfica al inglés, inmediatamente después de disponerlos en el idioma del texto original, si este no es ya en lengua inglesa. 


\section{CALL FOR PAPERS}

\section{Revista Internacional de Comunicación y Desarrollo, Num. 17, December 2022 - January 2023}

\section{Deadline: October, 15, 2022.}

The call for the submission of research articles for Issue 17 is open. The deadline for the submission of articles is October, 15, 2022. Once articles have been reviewed by RICD, authors will be notified of paper acceptance. Issue 17, that will be published online between December 2022 and January 2023, will preferently contain research articles related to the following lines of work:

\section{SDGs 14 and 15 in the training and information agendas. 2. Disinformation.}

The International Journal of Communication and Development from REAL-CODE (Red Europa y América Latina de Comunicación y Desarrollo https://www.real-code.org/), edited by the Service of Publications and Scientific Exchange of the University of Santiago de Compostela, is an online biannual journal of scientific dissemination which offers a critical interpretation about Communication and Development. We prioritize researches relating to both fields and their interrelations, especially those studies that count on the participation and support by social agents.

RICD is an open publication for those who want to share new methodologies and points of view related to social reality. RICD is indexed in Latindex, ERIH Plus, MIAR, Dulcinea and Dialnet.

RICD has a strict policy of revision in the section of research articles. We assume the doubleblind procedure and also the peer review.

RICD only accepts research articles never published previously. Reviewers will notify the editorial board if an article breaks basic ethical rules as re-edition or plagiarism. Those texts will be excluded from the edition in progress. RICD reserves the right to accept in the future new texts by those authors who have broken these guidelines.

RICD will take no responsibility for the review of the quoting, bibliographic references according to the APA style nor DOI inclusion, in case it proceeds. Thus, articles that do not meet these requirements will not be accepted.

The summaries and the originals must be formalized in Spanish, Portuguese, Galician language and/or English, according to the publication guidelines:

http://www.usc.es/revistas/index.php/ricd/about/submissions\#authorGuidelines.

After the original text, authors must always include the English translation of titles, summaries, key words, contents and biographical notes. 